Article

\title{
The Absence of the Right to Culture of Minorities within Minorities in Israel: A Tale of a Cultural Dissent Case
}

\section{Meital Pinto}

School of Law, Carmel Academic Center, 4 Shaar Palmer St., P.O. Box 33891, Haifa 33031, Israel; E-Mail: pintomei@carmel.ac.il; Tel.:+972-4-831-0001

Academic Editor: Frances Raday

Received: 25 March 2015 / Accepted: 13 August 2015 / Published: 1 September 2015

\begin{abstract}
The Israeli Plonit case concerns a Muslim woman who wished to be represented by a female arbitrator in a Shari'a Court. The Shari'a Court of Appeals denied her request and decided that Shari'a Law permits only men to serve as arbitrators. Plonit petitioned the Israeli Supreme Court, which accepted her petition and decided that the Shari'a Court of Appeals' decision infringed her right to equality. While I support the outcome of the Supreme Court's decision, my paper sheds a light on a crucial matter that is absent in the decision; namely, the right to culture of Muslim women, who are a vulnerable members of a minority group in Israel, and therefore constitute a "minority within minority". Analysing the case in terms of Plonit's right to culture, in addition to her right to equality, has two advantages. First, it stresses the main issues at the heart of the legal debate, which are the minority culture's norms and practices, and the right of the minority within the minority to influence and shape them as much as the majority within the minority. Second, when the minority within the minority's claim is put in terms of the right to culture, and not only in terms of the right to equality, they are not necessarily perceived by other minority members as claims that try to enforce external norms on the minority culture.
\end{abstract}

Keywords: Israel; Muslim; women; Jewish; feminism; Shari'a Court; group rights; the right to culture; multiculturalism; religious freedom 


\section{Introduction}

The Israeli Supreme Court has dealt with women rights that relate to multiculturalism and the protection of minority cultures [1-17]. ${ }^{1}$ However, as opposed to academic literature that refers in this regard to the right to culture of minorities and discuss it in depth, ${ }^{2}$ there is only one judicial decision in Israel that explicitly refers to the right to culture in the context of women rights within minority groups [13]. ${ }^{3}$

Relying on my previous work on the right to culture [36-38] and the role it should play in advancing claims of vulnerable minority members [38], this paper aims to point out the advantages of using the right to culture to advance claims of Muslim women as vulnerable members within the Muslim minority in Israel. ${ }^{4}$ By contrast to the mainstream academic literature, which employs the right to culture mainly in order to conceptualize claims of empowered minority members ([39,40]; [41], p. 213; [42,43]; [44], p. $24 ;[45]),{ }^{5}$ this paper offers a fresh feminist point of view that reconstructs the right to culture so it will accommodate claims of disempowered religious women in general and, specifically, disempowered Muslim women in Israel. In other words, this paper strives to put Muslim feminism ([50]; [51], pp. 323-38; [52], p. 12) in terms of the legal and philosophical literature concerning the right to culture. In line with literature associated with the third phase of feminism, this paper aims to contribute to "multiplicity of voices" as a "jurisprudential method" ([21], pp. 16, 263-65, 272-83) that, in turn, will change the interpretation of the right to culture, which is unfortunately currently understood as protecting the interests of empowered members within minority groups.

Plonit [17] is a good example of an Israeli case that deals with a legal claim brought by a vulnerable minority member. It concerns a Muslim woman who wishes to challenge a dominant cultural practice that allows only men to serve as arbitrators in Shari' a Courts. Plonit wishes to be represented by a female arbitrator in her divorce proceedings but the Shari'a Court, which represents the empowered members within the Muslim minority ([53], pp. 184-85) refuses her and claims that the dominant interpretation of Shari'a Law does not permit it.

Before delving into the Plonit case and before outlining the main argument this paper presents, it is necessary to briefly clarify what I mean by using the terms "culture" and "minority". The term "culture" refers to all kinds of cultures - religious, ethnic, linguistic, or otherwise. Religion should be understood as a cultural system ([54], pp. 87-125; [55], p. 381). That is, as a way of life that many people produce

1 For cases that concern Muslim women who challenge their inheritance share see [18].

2 For academic literature that explicitly discusses the right to culture with regard to the status of women within minority groups in Israel see for example [19-34].

3 The right to culture is generally rare in Israeli judicially decision. Except for the Rubinstein case, which dealt with core studies of ultra-orthodox male Jews [35], it does not explicitly appeared in judicial decisions.

4 Although this paper suggests a way in which the right to culture may improve the status of Muslim women and other women within religious minorities, it does not deal with the international law aspects of women's right to their culture.

5 Some scholars employ the right to culture of empowered minority members not in order to support their claims but rather in order to criticize them by pointing out the destructive role the right to culture plays in disempowering vulnerable minority members $[20,46]$. Others explicitly emphasize that the right to culture should not empower already powerful minority members on the expense of less empowered minority members [39,47,48]. Eminent feminists, who are very attentive to cultural differences, such as Ayelet Shachar [19] and Avigail Eisenberg [49], have suggested thoughtful and interesting ideas to make disempowered minority members more powerful within their minority groups. However, unlike my suggestion in this paper, Shachar's and Eisenberg's accounts do not reconstruct the right to culture. 
and share together ([38]; [56], p. 727; [57], p. 47) ${ }^{6}$. The term "minority" refers to a disempowered cultural community within larger society. It is the vulnerable civic status that defines minorities, rather than their numbers. Minority groups are defined in terms of unequal citizenship and belonging to general society. Unlike majority cultural communities, which enjoy representation, acceptance, and dominance in the public sphere, minority cultural communities are attached to vulnerable cultures that do not enjoy such a well-regard public status. Minority members are typically excluded or partly included in the political and civic life of general society. ${ }^{7}$

I will also use the term "minorities within minorities" as a key concept in order to refer to women as vulnerable members within minority groups. Minorities within minorities are defined in the academic literature as individuals or groups that, on the one hand, identify with their minority culture and are largely considered in general society as minority members but, on the other hand, resist prominent values and norms that are largely acceptable in their minority group and strive to change them. In most cases, these individuals or groups are more vulnerable in terms of their social status and political power in comparison to other minority members ([31], p. 293; [38]; [46], pp. 12, 22; [65], pp. 1-2, 5; [66], pp. 12, 157; [67], p. 5). In this regard, minorities within minorities are the opposite of "the majority within the minority"-a term that refers to empowered minority members who enjoy a higher social status within their minority group.

I will use the Plonit case to illustrate the absence of the right to culture from the judges' legal analysis and point out the advantages of employing it in order to advance legal claims of Muslim women as minorities within minorities. As I will explain, conceptualizing their claims by appealing to their right to culture, in addition to their individual rights to equality or liberty, better identifies the interests and the normative dilemmas that are at the core of the conflict. This is because of two main reasons. First and foremost, it explains their claims in terms that are not alienated from their cultural identity or external to the values and practices of their minority culture. It gives Muslim women and other vulnerable women within religious communities the option to put forward their legal claims without compromising their sense of personal and cultural identity. ${ }^{8}$ Second, it formulates their claims in terms that are not incommensurable to the majority within minority's claims. It therefore allows courts to properly address their claims and offer them a just resolution.

Part II outlines the facts of the Plonit case, and analyzes the decision delivered by the Israeli Supreme Court. Part III briefly explores two competing conceptions of the right to culture, namely rights of collective agents' conception, and rights to collective goods' conception, and argues on behalf of the second one. Part IV argues that because the right to culture protects the minority culture as a participatory object that is jointly produced and shared by all its members, majority within minority and minority

6 This is a functional definition of culture that can be contrasted with Rudolf Otto' substantive approach [58] that identifies the religious realm with the realm of "numinous", a term used by Otto to denote a non-rational and non-sensory experience or feeling which is both terrifying and fascinating at the same time. Under the substantive approach, the substance of religion as is perceived from the faithful's perspective. By identifying the religious realm with the realm of the "numinous", Otto aimed to grasp religion from within rather than from the outside (as suggested by the functional approach).

7 On the relation between citizenship, belonging, cultural differences and minority groups see ([37], pp. 705-6; [59]; [60], pp. 196, 224, 237; [61], pp. 22-23, 125-35; [62], pp. 480-81; [63], pp. 85-86; [64]).

8 On the correlation between the level of religious or ethnic identity and feminist political awareness of Muslim women see, for instance ([68], pp. 165-66, 168-70). 
within minority alike - are both entitled under the right to shape the values and the practices of their culture. Part V suggests that the Plonit case, and other similar cases in which vulnerable women within religious minority groups wish to dispute and revise values and norms that are internal to their minority culture, should be analyzed in terms of the right of minority within minority members to revise their culture vis-à-vis the majority within the minority's right to exclude them. Part V also offers a guideline for performing this balance by introducing a non-exclusive criterion for estimating the strength of the majority within minority's right to exclude minority within minority members.

\section{The Israeli Plonit Case}

The Israeli Plonit case [17] concerns a Muslim woman who requested a female arbitrator when she went through divorce proceedings in the Shari'a Court of Taibe, a town in Israel that is mostly populated by Israeli Arab citizens. Arbitration is an integral component of divorce proceedings, both as a means for reconciliation or peaceful separation and as a basis for the determination of fault, which has legal and financial implications for the "guilty" party $[69,70]$. After Plonit's request for a female arbitrator was turned down, she brought her request to the Shari'a Court of Appeal, which upheld the lower court's ruling that only men can serve as arbitrators. This is in spite of the fact that Israel's Shari'a courts apply article 130 of the Ottoman Family Law, which specifies that each member of a couple going through a divorce may choose an arbitrator to represent him or her, and that each arbitrator presents the needs and the interest of the represented party and supposed to have his or her best interests in mind [53]. The Shari'a Court justified its decision by saying that it had based its decision on interpretations of the Maliki, Hanafi, and Shafi'i schools of Shari'a Law. Plonit petitioned the High Court of Justice and argued that the Shari'a Court of Appeals' decision should be dismissed. The Israeli High Court of Justice accepted her petition.

Before analyzing the judges' decision, I would first like to lay out Plonit's argument before the Israeli High Court of Justice. Plonit's first argument was that article 130 of the Ottoman Family Law should be interpreted as all other laws in Israel, and should not be given a religious interpretation that follows Shari'a Law. According to Plonit's second argument, even if we accept the claim according to which the family Ottoman law is a religious law, it should be interpreted according to the Hanafi School of Islamic jurisprudence, which Shari'a courts accept on other matters, which allow women to be arbitrators. Plonit's third argument was that the Shari'a courts had exceeded their authority in disqualifying the female arbitrator out of hand and had violated Israel's laws on sexual equality. Plonit's fourth argument has been presented by Kayan, a feminist organization that aims at advancing the status of Arab women in Israel and protecting their rights. Kayan argued that the prevention of woman arbitrators in Shari'a courts undermines women's right to dignity, and that there is no relevant difference between men and women for the purpose of serving as arbitrators. Kayan has argued that women arbitrators would be able to more effectively serve women parties in court and, therefore, there is a need for women arbitrators to enforce women's right of expression. Kayan emphasized that the appointment of men to arbitrate women's cases in front of the court contributes to silencing their voices in the Muslim community.

The Israeli High Court of Justice overturned the decision of the Shari'a Court of Appeal prohibiting the appointment of a woman arbitrator in divorce proceedings, and sent the case back to the Shari'a Court, ordering it to allow the appointment of women arbitrators. This paper does not aim to criticize the result of the High Court's decision. Rather, it aims to shed a light on a crucial matter that is absence in the 
decision. The High Court's decision in Plonit was written by justice Arbel and most of it focuses on the issue of discrimination of women $[69,70]$. The central questions the court dealt with were whether the Shari'a Court of Appeal's decision prohibiting the appointment of a woman arbitrator discriminates against women, and whether it violates the Equal Rights for Women Law, which guaranteed women equality before the law. ${ }^{9}$ Justice Arbel dedicated significant parts of her decision to the importance of equality, especially the equality of women. ${ }^{10}$ She stressed that it is especially important to protect the equality of women in religious institutions that often perpetuate the inferior status of women. ${ }^{11}$ According to Justice Arbel, because the purpose of the Equal Rights for Women Law is to protect women and enhance their equal rights in society, it should be broadly interpreted and apply to all matters concerning women's rights. ${ }^{12}$

The result of the Plonit decision is wonderful, no doubt. However, in my opinion, the court should not have given such an exclusive place in its decision to the Equal Rights for Women Law. It should have also addressed Plonit's right to culture. As I see it, the central issue in Plonit is the social status of Muslim women within the Muslim community in Israel. Muslims constitute a minority group in Israel. The legal authority Shari'a courts have over family and religious matters of Muslims is given to them by the state of Israel as part of a set of group rights that aim to protect the Muslim religion and culture ([23], pp. 332-33; [71], p. 900; [72], pp. 64-65). Muslim women, who are of inferior social status within the Muslim community ([21], pp. 272-85); [73], p. 287; [74,75]), constitute a minority within minority.

There is no doubt that the Plonit decision improves the social status of Muslim women within the Muslim minority group in Israel. Plonit's result has been achieved mainly by broadly applying the Equal Rights for Women Law on Shari'a courts. In this regard, the Plonit decision joins other judicial decisions that conceptualize the problems of minorities within minorities as a conflict between the right to religious freedom or the right to culture of the majority within the minority, who are interested in protecting disputable religious or cultural norms, versus individual rights, such as the right to equality, of minorities within the minorities, who wish to challenge and revise them [38]. Such analysis is also prevalent among political theorists. It is called the "dominant" or "judicial" framework, and is associated with Susan Okin, Martha Nussbaum, Chandran Kukathas, and Jeff Spinner-Halev ([65], pp. 251-56; [76], pp. 113, 115). In the remainder of this paper, I will explain why I think this analysis is incomplete.

My essential argument is that the court could have achieved the same result by appealing to the right to culture of Muslim women in addition to Plonit's individual right to equality. The main advantage in appealing to the minority within minority's right to culture is symbolic or expressive. ${ }^{13}$ The right to equality is perceived like an individual right that is forced on the Muslim minority from "the outside", whereas the right to culture is perceived as protecting the Muslim minority culture, its values, and norms. When claims of minorities within minorities, such as Muslim women, are put in terms of their right to culture, they are perceived not as part of a struggle between the minority culture and the hegemonic majority culture, but as an inside legitimate struggle within the minority group on the meaning and the form of the minority culture's values and practices that are shared by all minority members.

\footnotetext{
9 Paragraph 5 of justice Arbel's decision.

10 Paragraphs 22-25 of justice Arbel's decision.

11 Paragraphs 25-26 of justice Arbel's decision.

12 Paragraph 31 of justice Arbel's decision.

13 On Expressive theories of law in general see [77,78].
} 
The struggle to put female voices in terms of the norms and values of the minority culture with which they are associated goes in direct line with the work of current Muslim feminist organizations in Israel and other countries in the Middle East ([52], pp. 16-20; [79], pp. 128-30; [80], pp. 151-58). For instance, the Nisa wa Afaq Organization, which is committed to feminist reading of Islamic tradition, does not focus on human rights as an instrument for a change, but rather on religion as the starting point of their struggle ([80], p. 151). Such organizations basically put forward the idea that Muslim women do not necessarily need the "West's version of feminism" [81] that "throw" them out of their minority culture. Instead, they need to put their claims in terms of their own culture so they will be able to change it from inside ([52], pp. 16-20; [82], pp. 570-72).

My argument relies on the right to culture of the minority within minority and its absence from academic literature and legal cases like Plonit that concern minorities within minorities. In order to understand it, we should first unfold the concept of the right to culture, its uses, its misuses, and its unfortunate absence from minorities within minorities' cases. The next section will be therefore dedicated to this end.

\section{The Right to Culture-A Right to a Participatory Good}

Claims of minority members who wish to protect their cultural norms and practices in multicultural societies are frequently conceptualized by lawyers and scholars as claims about the "right to culture", "group rights" or "collective rights" ([34,39-43,81,83-85]; [86], p. 42; [87-89]). For the sake of consistency and clarity, I will treat them as synonyms and address them as "claims for the right to culture". As I have indicated in the introduction, religion is understood in this paper as a specific kind of culture. Claims for the right to religious freedom should therefore be understood in this paper as reducible to the right to culture ([42], pp. 625-41; [90]; [91], p. 137; [92], pp. 287-89).

When it comes to minorities within minorities' cases, claims for the right to culture, brought on behalf of the majority members within the minority, are usually balanced or weighed against individual rights of minorities within minorities. However, the dichotomy of the right to culture versus individual rights is problematic because it frames the good of minority culture on the one hand and the goods of equality or freedom on the other as incommensurable goods. That is, as goods with no common base-line that could give policy makers an opportunity to balance the competing interests. The dichotomy of individual rights versus the right to culture, therefore, leaves judges and other policy makers with no other option but preferring one right over another ([49], pp. 71-72). The incommensurability problem is especially difficult for courts because their decisions in minorities within minorities' cases may seem to be based on arbitrary or idiosyncratic values, as they lack the capacity to balance the right to culture against individual rights on a principled basis ([49], pp. 73-74).

Following my previous work on minorities within minorities' cases [38], this paper challenges the familiar dichotomy between the right to culture and individual rights. Not all minorities within minorities' cases should be understood only in terms of the majority within minority's right to culture versus the individual rights of minority within minority members. Rather than conceptualizing them only in terms of individual rights, some claims of minorities within minorities are to be also understood in terms of the right to culture as well - the very same one that is claimed by the majority members within the minority.

However, what do we exactly mean by referring to the term "right to culture"? Why is it considered a group right? The answer to these questions should begin with an account of the term "right". According 
to Joseph Raz, the right to X exists if, and only if, some person's interest constitutes a sufficient reason for holding others to be under a duty to provide or to secure X ([93], p. 166). Following Raz's account of a right, the right to culture may be understood in two different, competing conceptions. The first conception focuses on the agent or agents that hold the right and is therefore called "rights of collective agents" [84]. The second one concentrates on the good or the interest that is protected by the right to culture and is therefore called "the rights to collective goods" ([84]; [94], p. 200). ${ }^{14}$ I will now briefly explain why it is the second conception that should generally serve as the focal point for conceptualizing the rights of minorities within minorities, and why it should specifically serve us in order to understand the right of Muslim women in the Plonit case.

Under the rights of collective agents' conception, a right might be considered to be a group right because it is the group, acting through its leadership, which has the legal power to invoke or waive the right. For example, a group's right to its land may be considered a group right because only the group acting through its leadership has the power to make decisions about the disposition of that land. Under the rights to collective goods' conception, a right may be considered to be a group right because the interests it protects are collectively shared by all group members rather than separately by each individual [84].

There are two reasons to object to the rights of collective agents' conception. First, we cannot hold it if we wish to adhere to the liberal framework of human rights. If we accept the collective agents' conception, we have to show that a group holds a right as a collective in order to argue that a right is a collective right. In other words, a right must amount to something more than the sum of the rights of its individual members in order to be understood as a collective right under the collective agents' conception. We must assume that there exists a collective that is irreducible to its members in the sense that its welfare is independent from the welfare of each of its members. If we cannot draw a distinction between a group and its members, then the right is in fact an individual right as it relates to the well-being of every individual in the group qua individual. In most cases, such a holistic approach towards a group of people proves hard to establish ([84], p. 319). The rights of the collective agents' conception is therefore not compatible with methodological individualism, which entails that culture cannot be understood as more than the shared aims of its members [97,98], and thus seems incompatible with liberalism.

Second, we should object to the rights of collective agents' conception because it assumes that groups qua groups play an active role in exercising, interpreting, and defending their rights. However, some groups may lack effective agency and clear identity. Effective agency is a matter of being able to form goals, deliberate, choose, intend, act, and carry out evaluation of actions taken. Groups, unlike normal individuals, may be internally divided, unorganized, unclear about their boundaries, and therefore face difficulties in engaging in actions as groups ([88], pp. 235-37; [96], pp. 135-40; [99], p. 257).

If we adhere to the second conception of the rights to collective goods, as I suggest we do, we are required to observe the character of the object or the interest a right protects in order to decide whether it is to be understood as a right to culture. The question is, therefore, which kind of goods need protection through the right to culture? The answer is a participatory good that is presented by Denise Réaume, who defines it as a special kind of good that can only be produced and shared by a group of individuals. That is, a participatory good by its very nature involves activities that require many in order to produce

14 These two approaches relate to a larger debate in rights' philosophy about the proper account of rights as protecting the holders' interests (as Raz and others suggest) or the holders' choices ([95], p. 191; [96], pp. 66-75). 
it. A participatory good is valuable only because of the joint involvement of many within it ([83], p. 10). It is the participatory character of the good that makes the right to culture different from individual rights. Cultures, which are often manifested and practiced by religion, are examples of participatory goods because they can only be created and enjoyed by a group of people rather than individuals. Therefore they are goods that merit legal protection by group rights. ${ }^{15}$

One may argue that the right to culture may be viewed as an individual right because when a person reads a book or prays alone she also practices her right to culture without necessarily needing the presence of other individuals who will participate and pray with her. ${ }^{16}$ In my view, such actions are also participatory in their nature as one cannot read a book or pray unless someone from her cultural community has written this book or created the practice of praying. Reading books or praying presupposes a community of writers, readers, thinkers, poets, and leaders who associate themselves with a cultural community. The requirement of other individuals that are required in order to produce and enjoy a culture is not only descriptive. ${ }^{17}$ It boils down to the normative value of culture itself. There is no way in which the interests in creating, sharing, enriching, valuing, disputing, and protecting a culture can be understood in individual terms.

At this point one may still insist that we should not conceptualize the right to culture as a group right. If the good that the right to culture protects is a participatory good that is valuable only because of the joint involvement of many individuals within it, why should we insist on defining the right to culture as a group right? The whole idea of group rights, one will argue, is alien to the liberal approach towards rights. According to the traditional view of liberalism, rights can be attributed only to individuals ([99], p. 257). By contrast to group rights, individual rights are also universal by their nature - they, at least potentially, apply to all individuals and benefit all individuals, without any reference to their community's

15 For the purpose of defending the participatory interest's conception of the right to culture, it is important to stress two points: First, it does not entail that a right to culture is only a right to a participatory good, but rather that a participatory good can only be protected by the right to culture ([83], p. 27; [88], p. 201). I choose the participatory good conception because, as I explained, it is the best way to understand the right to culture without the need to delve into questions regarding the identity of the group as the holder of the right to culture, and because such an endeavor takes us away from the general framework of human rights within liberalism. Second, one may argue that the right to association or the right to collective bargaining, which are also frequently referred to as "collective rights" ([100]; [101], p. 176), also have a participatory nature because they cannot be exercised only by an individual. However, this fact does not prove that it is a group right. The right to culture protects an already established participatory good, while the object of the right to association is a potential participatory good, i.e., a potential to create a future participatory good. Therefore, according to the second conception of group rights, which requires us to observe the character of the good that is protected by the right, the right to association is not a group right. Admittedly, the right to association cannot be exercised by one individual who lives in an isolated island. It requires preconditions such as the existence of people, who can practice it, and freedom of interaction between them. However, it does not require the precondition of an existing participatory good to protect. Unions and corporations are artificial entities that do not exist before the law recognizes them as such. Cultures on the other hand do not need an official legal status in order to be recognized by society as such. Cultures are recognized as participatory goods not by law but by objective criteria such as distinctive religious and linguistic practices, ideologies and symbols that mark a group of individuals as a cultural group ([96], pp. 123-27).

16 For an argument along this line see ([86], p. 43). Tamir does not use the term "participatory goods". She addresses the argument that supports defining rights as group rights because of their collective implementation.

17 For a discussion of the argument according to which the participatory interest's conception of group rights is merely a descriptive see ([99], p. 260). 
membership ([99], pp. 48-51; [102], p. 45). Along this line of reasoning, traditional accounts of liberalism, such as Rawls' theory of liberal justice, explicitly disregards the value of community membership. The dimension of affiliation with community is seen by Rawls as part of a comprehensive doctrine that cannot be recognized in the public sphere ([103], p. 201). Under this understanding, all persons are owed equality of rights based on respect for common human capacities, such as autonomy, rationality, morality, and dignity. By this route, we arrive at a neutral or "procedural" (or color-blind) liberalism that claims to respect individual difference, identity, and cultural attachment by ignoring them. For procedural liberalism, equality before the law and purely individual rights of citizenship free every person in the private sphere to embrace whatever cultural, religious, or personal attachments he chooses. From this standpoint, cultural difference exists only in the private sphere.

However, the answer to the one who insists on perceiving human rights only in individual terms by disregarding community differences is that even the liberal framework of human rights cannot ignore cultural or religious affiliation. Ignoring them will justify the critic on liberalism made by those who identify or identified as communitarians, such as Michael Sandel and Charles Taylor. As observed by Sandel, the traditional universal liberalist approach views the individual as an "unencumbered self", who lives his life without any sense of community or tradition. According to Sandel, this vision does not accord with the fact that each person is influenced by the community that surrounds him and in which he is situated ([104], p. 87; [105], p. 14). Taylor argues that a person's identity crucially depends on his dialogical relations with his community and society ([106], pp. 33-34). ${ }^{18}$ This dimension should be recognized in the public sphere. The recognition of different identities and different cultures in the public sphere, especially minority cultures that are constantly threatened by the majority group, is called, by Taylor, "the politics of recognition".

Sandel and Taylor's criticisms imply that if we respect persons, not only as human beings with common capacities, but also as particular individuals with cultural attachments to their minority cultural communities, then contrary to those who think that we better pursue justice for minority cultural groups in terms that are external to the realm of rights ([99], pp. 265-76), we ought to acknowledge the concept of group rights. Following Taylor's argument, when rights are understood in a group context they allow a politics of recognition of difference between groups with distinct cultural identities. ${ }^{19}$ They allow recognition of the equal value of different cultures. By not recognizing this value, a procedural liberalism sends a negative message to the members of minority groups according to which only the dominant majority culture is worthwhile. A member of the minority culture receives a message that her cultural identity is, in fact, inferior to that of the majority ([37]; [108], pp. 59, 66-67). A dominant culture that is unwilling to empower a minority culture with group rights such as the right to culture effectively attributes a lesser value to both the minority culture and those persons whose identities are associated with it. In fact, the message is that the dominant culture is the only genuine culture which is worth preserving. For those persons whose identities are tied to minority cultures, this message may offer alienation and despair. The group context of the right to culture allows us to take into account the relationship between groups and the role of these rights in promoting justice between such groups.

18 Margalit and Raz raise a similar claim when they argue that that people's sense of their own identity is bound up with their sense of belonging to groups and their self-respect is affected by the esteem in which these groups are held ([40], p. 87).

19 For an argument that establishes the idea of group rights on Taylor's theory of politics of recognition see ([107], pp. 668-70). 
The question now therefore is: why not recognize the right to culture as a group right? The reluctance to recognize group rights originates mainly from the fact that these kinds of rights may empower the group to interfere with the freedom of its individual members [20,24,34,46], especially with the freedom of the minority within minority members.

I would like to argue now that it is quite the opposite. Thinking about the right to culture in terms of a group right that protects a participatory good actually allows us not only to promote justice between the majority and the minority group but also to promote justice within members of the minority group, mainly justice for the minority within minority members. Drawing on my previous work on the subject of justice to minorities within minorities [38], I will now shortly unfold this argument.

If a participatory good is the shared production and enjoinment of a group of individuals, the premise is that it is an object that should always be conceived as a work in progress. Law protects minority cultures not because they are static, artistic objects that contribute to humanity as such, ${ }^{20}$ but because of their importance to the particular minority members who are deeply attached to them ([19], p. 72; [27], p. 285; [110], pp. 67-79; [111], p. 129; [112], pp. 509-23). That is, minority groups or minority cultures are not intrinsically valuable in themselves. They are valuable and justify legal protection by group rights only if they serve the individual interests of their members ([93], pp. 207-9). It is therefore only logical to assume that minority members are entitled to the protection of the right to culture even when they constantly dispute, change, and revise the norms and values of their culture. This is because as a participatory good, culture demands the production and enjoyment of all individuals who identify with it, along with their will to take part in it ([83], p. 17). As long as individuals identify themselves as attached to a particular culture, take active part in it, and are identified by other members of this culture as part of it, these individuals are entitled to employ the right to culture in court when they wish to revise or change this culture's norms or practices ([96], p. 127).

The premise of change that is inherent to all cultures, and the premise that all individual members of cultures are entitled to shape the content of their cultures, have a vital importance to our understanding of minorities within minorities' claims. As I will illustrate in the next section, some claims of minorities within minorities, like the Muslim woman in the Plonit case, express a will to dispute dominant norms and practices in their minority culture. They wish to change and revise basic norms in their culture so it will reflect the values of all minority members. Current literature about multiculturalism refers to these kinds of claims as cultural dissent ([112], pp. 509-23). That is, claims of minority members to have an influence on determining their minority group's course of action by voicing their immanent criticism about prevalent norms and practices in their minority culture that they would like to change or revise ([27], pp. 275-76; [113], p. 48). The Muslim woman's claim in Plonit comes to my mind in this context. The next section will be dedicated to explore it and point out the way it manifests the need to conceptualize cultural dissent claims in terms of the right to culture.

20 There are conceptions of culture, and especially of language (that usually represent culture), according to which minority cultures should be protected because they are like valuable artefacts that are in danger of extinction [109]. However, such conceptions are not consistent with human rights that are built on the notion of importance to individual humans rather than to humanity as a whole. 


\section{The Right to Culture of the Minority within the Minority in Plonit}

Plonit is a classic example of a case in which a minority within minority wishes to dissent, dispute, and revise dominant practices so they will reflect, at least to some extent, the values of all minority members. Plonit did not accept the dominant practice in her minority group that allows only men to serve as arbitrators in Shari'a courts. Plonit's request to appoint a female arbitrator on her behalf was a request to change a dominant practice in her culture so it would reflect the values and needs of Muslim women [59]. Plonit did not ask for the right to leave her minority group, or for the right to "exit" from it. ${ }^{21}$ She asked to revise the Muslim culture so it will accommodate the values and needs of Muslim women. That is, Plonit asked the Israeli High Court of Justice to protect the participatory good of her minority culture according to the way she understands it. However, although Plonit asked to protect a participatory good of a culture she identified with and belongs to, her claim was conceptualized by the court only in terms of equality, which is external to her minority culture.

My argument is, therefore, that Plonit's claim, and similar claims of minorities within minorities who wish to revise and change the content of their minority culture in similar circumstances, should not only be conceptualized in terms of equality. They should be also conceptualized in terms of their right to culture - the very same one they share with the majority within the minority. In other words, the right to culture protects Plonit just as much as it protects the Shari'a Court and the majority within the Muslim minority group. Therefore, the right to culture of the majority within the minority should not be balanced only against Plonit's right to equality, because the right to culture protects her as well. ${ }^{22}$

At this point, one may ask why the right to culture cannot suffice for conceptualizing Plonit's claim without the right to equality. My answer is that the right to equality should stay operative because it may be the case that the minority within the minority would urge the minority group to discriminate. Let us think, for instance, about a racist minority within a religious minority that refuses to allow blacks to use the religious minority's temple. In such cases of a conflict within the minority group, courts will have to decide which among the norms of the minority to enforce. Courts cannot make this decision by using the right to culture alone. In such cases, courts will need to use a secular norm, such as the right to equality, in order to decide which among the religious norms to select. Furthermore, there are issues in which there is no available feasible religious interpretation which supports the minority within minority's claim or, at least, the minority within minority's members do not raise such a claim. This is currently the case, for instance, regarding the right to a portion of the inheritance equal to that of men In Islam. In such cases, the right to culture can be of no use to minorities within minorities. A state court has no other option but to consider the minority within minority's right to equality. Moreover, as I have indicated in the first section, the current dominant legal framework in Israel does not officially acknowledge the right to culture, and certainly does not view it as standing on the same legal and constitutional level as the right to equality.

One may challenge my argument at a different level and ask how a state court can base its decision on cultural interpretation which supports women's right to have a female arbitrator, when this claim has

21 On the right to leave a minority culture or to exit from it see ([48]; [113]; [114], pp. 205-30; [115,116]).

22 For similar views, according to which conflicts between minorities within minorities, who wish to change and revise cultural practices of their minority group, and majority within minority members who wish to preserve them should not be conceived in terms of the right to equality against the right to culture see ([27], p. 275; [112], pp. 535-42). 
already been rejected by a competent Sharia court. What authority does a state court have to judge the proper interpretation of a religious code? Would such a judgment by a state court, contravening a Shari'a court, really have the advantages of greater acceptability in the Muslim community if the claim is based on the right to culture rather than a right to equality? Would it not rather be seen as an even greater intrusion by the state into the minority culture than reliance on the right to equality? If, as I suggest, minority communities are unhappy with human rights claims and court decisions, why should they be happy with the claim of a right to culture even though it is too, like the right to equality, a human right?

I do not claim, however, that appealing to the right to culture is preferable because it makes the majority within the minority more receptive to it or to the state court's authority. Rather, my claim is that this is the proper way to address such claims in state courts, both from a multicultural liberal normative perspective and from an analytic theory of rights' perspective. We should bear in mind that the Israeli Supreme Court has already intervened in decisions of religious tribunals and compelled them to apply human rights in decisions concerning religious issues such as inheritance and divorce ([117], p. 63; [118], pp. 510-11). ${ }^{23}$ The question of how receptive the majority within minority will be to the use of the right to culture and to the interpretation of their own cultural norms by the state courts requires further empirical study that exceeds the scope of this paper. This conclusion about the right to culture of Plonit to dispute, change, and revise the norms and values of her minority culture, which should be considered alongside with her right to equality, seems to be consistent with common methodologies of interpretation in Islam. As the well-known Egyptian Muslim feminist Nawal El Saadawi ([119], pp. 291-92) points out, Islam is not usually interpreted in a "rigid" and static manner. The methodology of igtihad that means original interpretation, which is not copied and not repeated, allows Islam to be adaptable to the needs of Muslim men and women these days. In the context of polygamy, for instance, El Saadawi refers to a group of Muslim thinkers who interpret the Koran to be unfavorable towards the notion of men who marry more than one wife ([119], p. 292).

In light of El Saadawi's suggestion regarding the issue of polygamy, there is no good reason to disregard the Hanafi interpretation of the Family Ottoman law that specifically allows woman to act as arbitrators in Shari'a courts. The Hanafi interpretation should be perceived in this context as a feminist tool that makes room for Muslim women within their own minority culture. There is no need to abandon Muslim women's right to culture in this case. Only to perceive it in a way that includes the needs and values of all minority members - men and women. Such a perception is consistent with a new wave of feminism that interpreters classic texts in Islam in a way that allows women to become agents of change within their own religious communities ([120], pp. 40-41).

23 Hacker [117] refers to two controversial decision of the Israeli Hugh Court of Justice that intervened in rabbinical courts' decision concerning religious issues. The first case is HCJ 1000/92, Bavli v. Great Rabbinical Court, [1994] 48(2) IsrSC 221. In Bavli, the Israeli Supreme Court overturned rabbinical court's decision, according to which an equal division of property between a husband and a wife after their divorce is in contradiction to Jewish religious. The High Court of Justice ruled that the rabbinical courts are obligated to implement the principle of equal property rights in cases of divorce. The second case is HCJ 6650/04, Doe v. District Rabbinical Court of Natanya [2006] 61(1) IsrSC 581. In this case, the High Court of Justice ruled that photographs showing the wife having sexual relations with another man cannot be submitted by the husband as evidence to the rabbinical court because they were taken without the wife's and therefore infringe on the wife's right to privacy. 
A feminist interpretation has been already applied in other issues concerning religious interpretation of Islam that effect Muslim women. Take the issue of inheritance for instance. Although according to Islamic law daughters are entitled to half the share of sons, the reality is that many Muslim women relinquish their share in favor of their brothers, mainly in order to receive recognition and respect from their family members for doing so [18]. The Nisaa wa Afak (Women and Horizons) is a feminist Muslim organization in Israel that strives to change this reality. It does so not by advocating for Muslim women's right to equality but rather by conducting lectures and providing information about Islamic law, which does not require Muslim women to give up their share of inheritance in favor of Muslim men ([80], pp. 157-58). Nisaa wa Afak does not specifically refer to the right to culture in this instance, but the motivation of its work is to create more room for women within Islam. This is exactly where the perception of the right to culture as a participatory good that includes the needs and values of all minority members comes at hand.

As the Nisaa wa Afak organization advocates, feminist interpretation of the Koran is not only available, but also necessary in order to promote the social status of women within the Muslim minority culture in Israel. In the words of Liat Kozma, a leading feminist historian, the idea is to empower and educate Muslim women without alienating them from their own minority culture and community ([80], p. 157). A different conclusion that perceives the right to culture as protecting only the needs and visions of the empowered members within the Muslim community, does not only harm disempowered Muslim women, but also contributes to a static version of Islam that does not allow any change and may consequently harm other disempowered minority members.

\section{The Right to Exclude and the Right to Revise in Plonit and in Other Similar Cases}

As I have explained in the previous part, we should perceive Plonit as a member of a disempowered group within the Muslim minority in Israel. That is, Plonit should be understood as a minority within minority member. I have also explained that in addition to the right to equality, Plonit's claim should be also considered as a minority within minority's claim to the right to culture because she is interested in changing, revising and influencing a prevalent norm in her own minority culture - the same one she shares with the majority within her minority group.

In other words, the Plonit's case is about two sub-groups within a cultural minority which hold irreconcilable views with regard to the shared desirable content of the culture's values and practices. If my argument is accepted, Plonit's claim should be considered as a claim about her right to culture. However, the Shari'a Court's argument is also about the way a prevalent norm in the Muslim culture (arbitration in Shari'a Courts) should be interpreted and practiced. If my argument is correct, then the Shari'a's Court's claim should also be considered as a claim about the right to culture. At this point, one may ask how courts should resolve such a case. That is, how courts should balance a minority within minority's right to culture when the majority within the minority raises a conflicting claim in the name of the right to the same culture?

Drawing on my previous work [38], my answer to this question relates to the fact that typically, in cases such as Plonit, the minority within minority wishes to revise prevailing norms of the minority culture, while the majority within minority wishes to maintain them, and exclude minority members who do not conform to them. In such cases we should therefore derive two different rights from the right to 
culture that protects all minority members. The first is the minority within minority's right to revise prevailing cultural norms and values of the minority group, and the second is the majority within minority's right to exclude minority members who wish to challenge common cultural practices.

Acts of exclusion of minorities within minorities are usually inherent to values or norms the majority within minority tries to impose upon all minority members. As a result, the majority within the minority usually exercise their right to exclude by refusing to share a benefit or a good with the minorities within minorities in spite of the fact that this good is a product that has been produced by all minority members. Acts of exclusion may take different forms. In an earlier work [38] I have presented three non-exclusive examples of exclusion forms. First, majority members within the minority may exclude other minority members by denying them membership in one or many of the institutions in which their minority culture operates. Second, they may exclude minorities within minorities by severely limiting their options to enjoy a good or a benefit that is part of their culture. Finally, majority members within minority cultures may impose certain discriminatory norms upon minorities within minorities that limit their autonomy to enjoy specific goods in general society in which they live.

A good example of the first kind of exclusion (denying membership in one or many of the minority culture's institutions) was presented in a petition brought to the Israeli High Court of Justice by Ruth Colian, a Jewish Ultra-Orthodox woman who was excluded from being considered as a candidate to the Ultra-Orthodox political parties' lists, which have always been exclusively preserved for Ultra-Orthodox men [16]. Colian called the state to cut funding to political parties that discriminate against women by banning women from running for office. On several interviews to the Israeli media, Colian explained that it was important for her to run as part of an ultra-orthodox party, rather than other political parties in Israel, because she wanted to show a different side of the Jewish religion and the ultra-orthodox culture and community. The Ultra-Orthodox political parties, which are part of the respondents in this case, argue that they do not discriminate against women or deny them their right to be elected because electing women to be official representatives in the parliament or in city councils contradicts the halacha (Jewish Law).

The Plonit case is a good example of the second form of exclusion (severely limiting minority within minority's options to enjoy a good or a benefit that is part of their culture) because Plonit, who belongs to the minority within minority, in this case has been denied the good of being represented by her chosen female arbitrator in the Shari'a Court.

The Women of the Wall cases [3-5,12], which concern religious Jewish women who insist on praying at the plaza of the Wall (known in Hebrew as "the Kotel") albeit fierce attempts of the orthodox majority within the minority of the religious Jewish community to deny them from doing so, illustrates the third kind of exclusion (imposing discriminatory norms upon minorities within minorities that limit their autonomy to enjoy specific goods in general society).

The Women of the Wall case is very unique. It is hard to think of a similar case outside Israel. It therefore requires a short introduction. The Kotel is the surviving remnant of the holly second Temple which was destroyed in $70 \mathrm{CE}$. The Kotel has been, since the destruction of the Temple, the most sacred site for the Jewish people. The Women of the Wall prayed in a group, wearing tallits (praying shawls), and reading aloud from a Torah scroll. Before the Women of the Wall, there have been only men who prayed like this, in the men's section at the Wall plaza. Until then, women prayed quietly rather than aloud, privately rather than in a group, and they were not permitted to wear prayer shawls and carry Torah scrolls or read from them ([121], pp. 120-28; [122], pp. XXII-XXVIII). 
The elements of wearing a tallit and reading from the Torah scroll are elements that Women of the Wall believe are allowed to women by the halacha (Jewish Law), even though many orthodox leaders disagree. The denial of the Women of the Wall to pray according to the way they chose to conduct their prayers has been justified by religious norms regarding the role of women as wives and care-takers who are to be confined to the private sphere, while leaving the public sphere solely for men ([121], pp. 120-28; [122], pp. XXVII-XXXI).

The government refused to allow the Women of the Wall to conduct their prayers in the specific way they wished to do so. The government claimed that because the Women of the Wall pray at the Kotel in a controversial way, they offend the religious feelings of other prayers at the Kotel, who, as a result, attacked the Women of the Wall and tried to stop them ([122], pp. XXVII-XXIX).

The first Supreme Court's judgment regarding the Women of the Wall's petition to pray in their own way at the Kotel was delivered by three judges. All of them agreed that the right to religious freedom protects Women of the Wall and allows them to pray at the Kotel. They disagreed on whether the Women of the Wall's right to religious freedom allows them to pray in their own distinctive and specific way ([3], p. 8). The late justice Elon, who was a leading expert on Jewish Law, explicitly ruled that halach does not necessarily forbid women to pray in the specific way the Women of the Wall wanted to perform their prayers at the Kotel. However, justice Elon decided to reject the Women of the Wall's petition because their prayers offend the religious feelings of prayers at the kotel ([3], pp. 8-9).

Religious feelings are mediated by cultural norms and values that are central to the cultural identity of the offended group or individuals [37]. Religious feelings are therefore more offended when the values and norms at hand belong to a minority culture that is in an imminent threat from the majority culture [37]. Therefore, although the government does not specifically use the term "right to culture", it basically appeals to it when it claims that Women of the Wall offend religious feelings of the Jewish prayers at the Kotel.

The question is how to balance the majority within minority's right to exclude against the right to revise of the minority within minority in cases such as Plonit, Colian, and Women of the Wall? I would like to suggest here a guideline that should be considered in order to evaluate the strength of the majority-within minority's claim to have a right to exclude the minority within minority. As other scholars have pointed out, the central task that should be performed in this regard is examining the genuineness of the majority within minority's claim to exclude the minority within a minority ([27], pp. 304-8; [123], pp. 258-67). The act of exclusion is usually justified in the name of values and norms that are allegedly central to the minority culture. Judges are usually not experts in most fields relating to cases they need to resolve, such as education, religion, medicine, transportation, psychology and the like. Similarly, judges are not experts in cultural norms and values. Albeit their non-expertise, they should not take claims about values and norms that are allegedly central to the minority culture without questioning them. They should investigate whether controversial practices of excluding minorities within minorities are really central and crucial to the cultural identity of the minority culture at hand or not.

I suggest two non-exclusive indicators that may be taken into account in such examinations. First, courts may ask whether there is a leader or leaders in the minority cultural community who object the act of exclusion on the ground that the culture's main values should not necessarily be interpreted as justifying the exclusion of vulnerable minority members ([27], pp. 305-6). If there is such a leader or leaders, this fact serves to weaken the majority within minority's right to exclude. The fact is that all cultures, including religious ones, are subjected to different interpretations. Take the Plonit case 
for instance; one school of Islamic law suggests that women may act as arbitrators in Shari'a courts, another school of Islamic law suggests that they do not. The same interpretation disputes also exist with regard to the issue of women serving as judges (Kadis) in Shari'a courts. In Israel there are no women serving as Kadis. In the Palestine Authority, two women have been recently appointed as Kadis ([124], p. 240, footnote15).

Second, courts should examine the necessity of the specific form the act of excluding minorities within minorities takes in order to protect the alleged cultural values that are invoked by the majority within minority. If no act of exclusion is really necessary in order to protect the cultural values invoked by the majority within the minority, or if the exclusion act is necessary, but not in its specific controversial form, this fact serves to weaken the majority within minority's right to exclude minority within minority members.

Let us apply these two indicators on the Women of the Wall case [3-5,12]. Not all Jewish rabbis and leaders view the way the Women of the Wall wish to pray at the Kotel as contradicting the halacha. There are many reform and conservative Jewish leaders who clearly think that there is no rule in halach that forbid them to do so. In fact, there are even some leading orthodox Jewish leaders who clearly state that halacha does not forbid them to do so ([121], pp. 120-28; [122], pp. XXVII-XXIX).

In other words, there is no necessity in Judaism that the excluding practice take this specific form to protect the norms and values that allegedly justify the act of excluding the Women of the Wall. ${ }^{24}$ If the exclusion practice is not really necessary to protect the minority's values and norms, this fact serves to weaken the state's claim that the exclusion is necessary in order to protect the religious feelings of the majority within minority. That is, this fact serves to weaken the majority within minority's right to exclude.

\section{Conclusions}

Lawyers, judges, and (mainly) legal scholar usually employ the right to culture for two purposes. The first is protecting the interests of dominant members within minority cultures, and the second is criticizing the role the right to culture allegedly plays in disempowering vulnerable minority members. The right to culture is notably absent when it comes to conceptualizing and advancing the interests of disempowered members within cultural minorities. In this paper I presented the Israeli case of Plonit in order to illustrate the absence of the right to culture and the important role it could play in advancing claims of religious women as vulnerable members within cultural minorities.

I have explained that conceptualizing claims of vulnerable religious women in terms of their right to culture, in addition to their individual rights, better identifies the human interests and the normative dilemmas that are at the core of the conflict. This is because their right to culture explains their claims in terms that do not alienate them from their own minority culture's values and practices, and because it formulates them in terms that are not incommensurable to the majority within minority's claims. It therefore allows courts to properly address their claims and offer them a just resolution.

24 More generally, there is no "one" accepted interpretation of Jewishness in Israel as such. See [125,126]. 


\section{Acknowledgments}

The author is greatly indebted to Moussa Abou Ramadan, who introduced me to the Plonit case, to Ilan Saban and Karin Carmit Yefet, who gave me great input on my arguments, and to Frances Raday, who kept challenging my arguments. The author would also like to thank Rhona Schuz and Ayelet Blecher-Prigat for organizing a round table on the Plonit case, and for inviting me to speak and learn from other scholars who contributed to my thoughts about the status of women in religious minority groups.

\section{References and Notes}

1. CA 245/81 Sultan v. Sultan, 38(3) PD 169 [1984].

2. HCJ 4298/93 Mona Jabareen v. Ministry of Education, 42(2) PD 221 (1993).

3. HJC 257/89 Hoffman v. Commissioner of the Western Wall 48(2) P.D. (1994) 265 (in Hebrew).

4. HCJ 3358/95 Hoffman v. Director General of Prime Minister Office.

5. HCJFH 4128/00 Director-General of Prime Minister's Office v. Hoffman. 57(3) P.D. 280 [2003].

6. HCJ 151/11 The Ruth and Emanuel Rackman Center for the Advancement of Women's Status v. The Ministry of Justice (27 December 2011).

7. HCJ 153/87 Shakdiel v. Minister of Religious Affairs [19 May 1988]. Available online: http://versa.cardozo.yu.edu/sites/default/files/upload/opinions/Shakdiel\%20v.\%20Minister\%20of \%20Religious\%20Affairs.pdf (accessed on 17 January 2015).

8. HCJ 1/88 Poraz v. Tel Aviv City Council, 42(2) P.D. 309 (regarding the body electing the Tel Aviv Municipal Rabbi).

9. HCJ 6300/93 The Institute for Training of Female Rabbinical Court Pleaders v. The Minister of Religious Affairs, 48(4) P.D. 441 [1994].

10. CA 3077/90 Plonit v. Ploni 49(2) PD 578 [1995].

11. HCJ 9611/00 Mari'ee v. Mari'ee, 58(4) PD 256 [2004].

12. Days Detention Appeal (Jer.) 23834-04-13 The State of Israel v. Ras. April 24th 2013. Summary available online: http://www.colman.ac.il/research/research_institute/katedra_HumanRights/Psika/ Documents/9/9_june_2013_3_Lahav_EN.pdf (accessed on 21 August 2015).

13. "HCJ 746/07 Ragen v. Ministry of Transport." 5 January 2011. Available online: http://versa.cardozo.yu.edu/sites/default/files/upload/opinions/Ragen\%20v.\%20Ministry\%20of\% 20Transport.pdf (accessed on 17 January 2015).

14. HCJ 856/07 Mavoi Satom (Dead End) v. the Committee for Appointing Rabbinical Judges (3 June 2008).

15. "CrimA 10828/03 Najar v. State of Israel." 28 July 2005. Available online: http://versa.cardozo.yu.edu/sites/default/files/upload/opinions/Najar\%20v.\%20State\%20of\%20Israel. pdf (accessed on 17 January 2015).

16. HCJ 7717/13 Colian v. The Finance Minister (2 October 2014).

17. HCJ 3856/11 Plonit v. The Shari'a Court of Appeal (23 June 2013).

18. Sandberg, Haim, and Adam Hofri. “Arab Israeli Women's Renunciation of Their Inheritance Shares: A Challenge for Israel's Courts.” International Journal of Law in Context 8 (2012): 253-67.

19. Shachar, Ayelet. Multicultural Jurisdictions. New York: Cambridge University Press, 2001. 
20. Raday, Frances. "Culture, Religion, and Gender." ICONS 1 (2003): 663-715.

21. Halperin-Kaddari, Ruth. Women in Israel: A State of Their Own. Philadelphia: University of Pennsylvania Press, 2004.

22. Halperin-Kaddari, Ruth. "Women, Religion and Multiculturalism in Israel." UCLA Journal of International Law and Foreign Affairs 5 (2000): 339-66.

23. Karayanni, Michael M. "Two concepts of group rights for the Palestinian-Arab minority under Israel's constitutional definition as a 'Jewish and democratic' state." ICONS 10 (2012): 304-39.

24. Karayanni, Michael M. "Groups in Context." Law and Social Inquiry, 2015, forthcoming.

25. Harel, Alon. "Benign Segregation: A Case Study of the Practice of Gender Separation in Buses in the Ultra-Orthodox Community." South African Human Rights Law Journal 20 (2004): 64-85.

26. Mautner, Menachem. Law and the Culture of Israel. Oxford and New York: Oxford University Press, 2011.

27. Ben-Shemesh, Yaacov. "Law and Internal Cultural Conflicts." Law and Ethics of Human Rights 1 (2007): 271-308.

28. Stopler, Gila. "Contextualizing Multiculturalism: A Three Dimensional Examination of Multicultural Claims." Law and Ethics of Human Rights 1 (2007): 1-45.

29. Hostovsky Brandes, Tamar. "Separate and Different: Single-Sex Education and the Quest for Equality." Israel Law Review 45 (2012): 235-66.

30. Perez, Nahshon. "Should Multiculturalists Oppress the Oppressed? On Religion, Culture and the Individual and Cultural Rights of Un-Liberal Communities." Critical Review of International Social and Political Philosophy 5 (2002): 51-79.

31. Perez, Nahshon. "Why Tolerating Illiberal Groups is Often Incoherent: On Internal Minorities, Liberty, 'Shared Understandings' and Skepticism." Social Theory and Practice 36 (2010): 291-314.

32. Jobani, Yuval, and Nahshon Perez. "Toleration and Illiberal Groups in Context: Israel's Ultra-Orthodox 'Society of Learners'.” Journal of Political Ideologies 19 (2014): 78-98.

33. Jobani, Yuval, and Nahshon Perez. "Women of the Wall: A Normative Analysis of the Place of Religion in the Public Sphere." The Oxford Journal of Law and Religion 3 (2014): 484-505.

34. Rubinstein, Amnon. "The Decline, but not Demise, of Multiculturalism." Israel Law Review 40 (2007): 763-810.

35. HCJ 3752/10 Rubinstein v. The Knesset (17 September 2014).

36. Pinto, Meital. "On the Intrinsic Value of Arabic in Israel-Challenging Kymlicka on Language Rights." Canadian Journal of Law and Jurisprudence 20 (2007): 143-72.

37. Pinto, Meital. "What Are Offences To Feelings Really About? A New Regulative Principle for the Multicultural Era." Oxford Journal of Legal Studies 30 (2010): 695-723.

38. Pinto, Meital. "The Right to Culture, the Right to Dispute and the Right to Exclude : A New Perspective on Minorities within Minorities." Ratio Juris, 2015, forthcoming.

39. Kymlicka, Will. Multicultural Citizenship. Oxford: Oxford University Press, 1995.

40. Margalit, Avishai, and Joseph Raz. "National self-determination." In The Rights of Minority Cultures. Edited by Will Kymlicka. Oxford: Oxford University Press, 1995, pp. 79-92.

41. MacIntyre, Alasdair. "Is Patriotism a Virtue?” In Theorizing Citizenship. Edited by Ronald S. Beiner. Albany: State University of New York Press, 1995. 
42. Sapir, Gidon. "Religion and State-A Fresh Theoretical Start." Notre Dame Law Review 75 (1999): 579-654.

43. Levy, T. Jacob. The Multiculturalism of Fear. Oxford: Oxford University Press, 2000.

44. Blake, Michael, and Mathias Risse. "Migration, Territoriality, and Culture." KSG Working Paper No. RWP07-009, Kennedy School of Government, Harvard University, Cambridge, MA, USA, February 2007. Available online: http://ssrn.com/abstract=963130 (accessed on 21 August 2015).

45. Gibson, Johanna. "The UDHR and the Group: Individual and Community Rights to Culture." Journal of Public Law and Policy 30 (2008): 285-317.

46. Moller Okin, Susan. "Is Multiculturalism Bad for Women?" In Is Multiculturalism Bad for Women? Edited by Joshua Cohen, Matthew Howard and Martha C. Nussbaum. Princeton: Princeton University Press, 1999, pp. 9-24.

47. Stopler, Gila. "A Rank Usurpation of Power-The Role of Patriarchal Religion and Culture in the Subordination of Women.” Duke Journal of Gender Law and Policy 15 (2008): 365-97.

48. Green, Leslie. "Rights of Exit." Legal Theory 4 (1998): 165-85.

49. Eisenberg, Avigail. Reasons of Identity: A Normative Guide to the Political and Legal Assessment of Identity Claims. New York: Oxford University Press, 2009.

50. Badran, Margot. "Islamic feminism: What's in a name?" Al-Ahram Weekly Online, 2002. Available online: http://weekly.ahram.org.eg/2002/569/cu1.htm (accessed on 21 August 2015).

51. Badran, Margot. Feminism in Islam: Secular and Religious Convergences. Oxford: Oneworld Publications, 2009.

52. Kozma Liat, Ruth Roded, and Naifa Sarisi. "Introduction." In Facing the Shari'a Court: Transformations in the Status of Muslim Women in Israel and the Middle East. Edited by Liat Kozma. Tel-Aviv: Resling Publications, 2011, pp. 1-20. (In Hebrew)

53. Abed Rabu, Laila. "The Shari'a Court and the Empowerment of Women." In Facing the Shari'a Court: Transformations in the Status of Muslim Women in Israel and the Middle East. Edited by Liat Kozma. Tel-Aviv: Resling Publications, 2011, pp. 183-99. (In Hebrew)

54. Geertz, Clifford. "Religion as a Cultural System." In The Interpretation of Cultures. Edited by Clifford Geertz. New York: Basic Books, 1973, pp. 87-125.

55. Friedman, Lawrence M. "The War of the Worlds: A Few Comments on Law, Culture, and Rights." Case Western Reserve Law Review 47 (1997): 379-88.

56. Esau, Alvin J. "Islands of Exclusivity: Religious Organizations and Employment Discrimination." University of British Columbia Law Review 33 (2000): 719-827.

57. Danchin, Peter G. "Suspect Symbols: Value Pluralism as a Theory of Religious Freedom in International Law." Yale Journal of International Law 33 (2008): 1-61.

58. Otto, Rudolf. The Idea of the Holy: An Inquiry into the Non-Rational Factor in the Idea of the Divine and Its Relation to the Rational. Translated by John Wilfred Harvey. London: Oxford University Press, 1923.

59. Shachar, Ayelet. "Whose Republic? Citizenship and Membership in the Israeli Polity." Georgetown Immigration Law Journal 13 (1999): 233-72.

60. Parekh, Bhikhu. Rethinking Multiculturalism: Cultural Diversity and Political Theory, 2nd ed. London: Palgrave, 2000. 
61. Shafir, Gershon, and Peled, Yoav. Being Israeli: The Dynamics of Multiple Citizenship. Cambridge: Cambridge University Press, 2002.

62. Volpp, Leti. "Divesting Citizenship: On Asian American History and the Loss of Citizenship through Marriage." University of California Law Review 53 (2005): 405-84.

63. Kostakopoulou, Dora. “Thick, Thin And Thinner Patriotisms: Is This All There Is?" Oxford Journal of Legal Studies 26 (2006): 73-106.

64. Wiles, Ellen. "Headscarves, Human Rights, and Harmonious Multicultural Society: Implications of the French Ban for Interpretations of Equality." Law \& Society Review 41 (2007): 699-736.

65. Eisenberg, Avigail, and Jeff Spinner-Halev. "Introduction." In Minorities within Minorities: Equality, Rights and Diversity. Edited by Avigail Eisenberg and Jeff Spinner-Halev. Cambridge: Cambridge University Press, 2005, pp. 1-15.

66. Phillips, Ann. Multiculturalism without Culture. Princeton: Princeton University Press, 2007.

67. Dick, Caroline. The Perils of Identity: Group Rights and the Politics of Intragroup Difference. Vancouver: University of British Columbia Press, 2011

68. Fuleihan, Nada S. "In Search of Identity: Hijab Recollections from West Beirut." In Muslim Women in War and Crisis: Representation and Reality. Edited by Faegheh Shirazi. Austin: University of Texas Press, 2010, pp. 165-73.

69. Batshon, Shirin. "The Arbitrator Case and the Equal Rights for Women Law." Mishpacha Bamishpat (Family in The Law), 2015, forthcoming.

70. Abou Ramadan, Moussa. "Hybrid Law and Patriarchal Liberalism: A Woman as Arbitrator in a Sharia Court." Mishpacha Bamishpat (Family in The Law), 2015, forthcoming.

71. Saban, Ilan. "Minority Rights in Deeply Divided Societies: A Framework for Analysis and the Case of the Arab-Palestinian Minority in Israel." New York University Journal of International Law and Politics 36 (2003-2004): 885-1003.

72. Karayanni, Michael M. "Separate Nature of the Religious Accommodations for the Palestinian-Arab Minority in Israel." Northwestern University Journal of International Human Rights 5 (2006-2007): 41-71.

73. Cohen, Orna, and Rivka Savaya. "Lifestyle Differences in Traditionalism and Modernity and Reasons for Divorce among Muslim Palestinian Citizens of Israel." Journal of Comparative Family Studies 34 (2003): 283-302.

74. Rouhana, Hoda. "Muslim family laws in Israel: The role of the state and the citizenship of Palestinian women.” In Dossier 27. London: Women Living Under Muslim Laws, 2006. Available online: http://www.wluml.org/node/501 (accessed on 21 August 2015).

75. The Working Group on the Status of Palestinian Women Citizens of Israel. "The Status of Palestinian Women Citizens of Israel: Submitted to the Committee on the Elimination of Discrimination against Women.” 2010. Available online: http:/www2.ohchr.org/english/bodies/ cedaw/docs/ngos/WomenCitizens_of_Israel_for_the_session_Israel_CEDAW48.pdf (accessed on 21 August 2015).

76. Phillips, Anne. "Dilemmas of Gender and Culture: The Judge, the Democrat and the Political Activist." In Minorities within Minorities: Equality, Rights and Diversity. Edited by Avigail Eisenberg and Jeff Spinner-Halev. Cambridge: Cambridge University Press, 2005, pp. 113-34. 
77. Anderson, Elizabeth S., and Richard H. Pildes. "Expressive Theories of Law: A General Restatement." University of Pennsylvania Law Review 148 (2000): 1503-76.

78. Sunstein, Cass R. "On the Expressive Function of Law." University of Pennsylvania Law Review 144 (1996): 2021-54.

79. Tzoreff, Mira. "The others of the others - Women, gender and nationality in the Palestinian society in the shadow of the intifadas." In Women in the Middle East: Between Tradition and Change. Edited by Ofra Bengio. Tel Aviv: Tel Aviv University Press, 2004, pp. 128-30. (In Hebrew)

80. Kozma, Liat. “The case of Palestinian Women's NGO in Israel." In Women and Knowledge in the Mediterranean. Edited by Fatima Sadiqi. London and New York: Routledge, 2013, pp. 144-64.

81. Janmohamed, Shelina. "British Muslim women don't need the West's version of feminism, OK?" The Telegraph Thursday, 19 February 2015.

82. Yefet, Karin Carmit. "The Pakistani Constitution and Female-Initiated Divorce: Western Liberalism in Islamic Garb.” Harvard Journal of Law \& Gender 44 (2011): 553-615.

83. Réaume, Denise. "Individuals, Groups, and Rights to Public Goods." University of Toronto Law Journal 38 (1988): 1-27.

84. Green, Leslie. "Two Views of Collective Rights.” Canadian Journal of Law and Jurisprudence 4 (1991): 315-27.

85. McDonald, Michael. "Questions about Collective Rights." In Language and the State: The Law and Politics of Identity. Edited by David Schneiderman. Montreal: Les Editions Yvon Blais, 1991, pp. 3-35.

86. Tamir, Yael. Liberal Nationalism. Princeton: Princeton University Press, 1993.

87. Tamir, Yael. “Against Collective Rights.” In Multicultural Questions. Edited by Steven Lukes and Christian Joppke. Oxford: Oxford University Press, 1999, pp. 158-80.

88. Nickel, James W. "Group Agency and Group Rights.” In Ethnicity and Group Rights. Edited by Ian Shapiro and Will Kymlicka. New York: New York University Press, 1997. pp. 235-56.

89. Newman, Dwight. "Collective Interests and Collective Rights." American Journal of Jurisprudence 49 (2004): 127-64.

90. Waldron, Jeremy. "One Law for All? The Logic of Cultural Accommodation." Washington and Lee Law Review 59 (2002): 3-34.

91. Medina, Barak. "Enhancing Freedom of Religion through Public Provision of Religious Services." Israel Law Review 39 (2006): 127-57.

92. Dorfman, Avihay. "Freedom of Religion." Canadian Journal of Law and Jurisprudence 21 (2008): 279-320.

93. Raz, Joseph. The Morality of Freedom. Oxford: Clarendon Press, 1986.

94. Newman, Dwight G. "Value Collectivism, Collective Rights, and Self-Threatening Theory." Oxford Journal of Legal Studies 33 (2013): 197-210

95. Harel, Alon. "Theories of Rights." In Blackwell's Guide to The Philosophy of Law and Legal Theory. Edited by Martin P. Golding and William Edmundson. Malden: Blackwell Publishing, 2005, pp. 191-206.

96. Jovanović, Miodrag A. Collective Rights: A legal Theory. Cambridge: Cambridge University Press, 2012.

97. Agassi, Joseph. "Methodological Individualism.” The British Journal of Sociology 11 (1960): 244-70. 
98. Heath, Joseph. "Methodological Individualism." In The Stanford Encyclopedia of Philosophy. Edited by Edward N. Zalta. Stanford: Center for the Study of Language and Information (CSLI), Stanford University, 2012. Available online: http://plato.stanford.edu/archives/spr2005/entries/ methodological-individualism/ (accessed on 21 August 2015).

99. Griffin, James. On Human Rights. Oxford: Oxford University Press, 2008.

100. Stone, K. Van Wezel. "The legacy of industrial pluralism: The tension between individual employment rights and the New Deal collective bargaining System." The University of Chicago Law Review 59 (1992): 575-644.

101. Brunelle, Christian. "The Emergence of Parallel Identity-Based Associations in Collective Bargaining Relations." In New Perspectives on the Public-Private Divide. Vancouver: UBC Press, 2003, pp. $166-86$.

102. Beitz, Charles R. The Idea of Human Rights. Oxford and New York: Oxford University Press, 2009.

103. Rawls, John. Political Liberalism. New York: Columbia University Press, 1993.

104. Sandel, Michael J. "The Procedural Republic and the Unencumbered Self." Political Theory 12 (1984): 81-96.

105. Sandel, Michael J. "The Order of the Coif Annual Lecture: The Constitution of the Procedural Republic: Liberal Rights and Civic Virtues.” Fordham Law Review 66 (1997): 1-2.

106. Taylor, Charles. "The Politics of Recognition." In Multiculturalism: Examining the Politics of Recognition. Edited by Amy Gutmann. Princeton: Princeton University Press, 1992, pp. 25-73.

107. Doppelt, Gerald. "Illiberal Cultures and Group Rights: A Critique of Multiculturalism in Kymlicka, Taylor, and Nussbaum.” Journal of Contemporary Legal Issues 12 (2002): 661-92.

108. Galeotti, Anna E. Toleration as Recognition. Cambridge: Cambridge University Press, 2002.

109. Réaume, Denise, and Meital Pinto. "Philosophy of Language Policy." In The Cambridge Handbook of Language Policy. Edited by Bernard Spolsky. Cambridge: Cambridge University Press, 2012, pp. 37-58.

110. Raz, Joseph. "Multiculturalism: A Liberal Perspective.” Dissent 41 (1994): 67-79.

111. Réaume, Denise G. "Justice between Cultures: Autonomy and the Protection of Culture Affiliation." University of British Columbia Law Review 29 (1995): 117-42.

112. Sunder, Madhavi. "Cultural Dissent." Stanford Law Review 54 (2001): 495-567.

113. Newman, Dwight G. "Exit, Voice, and 'Exile': Rights to Exit and Rights to Eject." University of Toronto Law Journal 57 (2007): 43-79.

114. Moller Okin, Susan. "Mistresses of Their Own Destiny: Group Rights, Gender, and Realistic Rights of Exit." Ethics 112 (2002): 205-30.

115. Reitman, Oonagh. “On Exit.” In Minorities within Minorities: Equality, Rights and Diversity. Edited by Avigail Eisenberg and Jeff Spinner-Halev. Cambridge: Cambridge University Press, 2005, pp. 189-208.

116. Spiecker, Ben, Doret De Ruyter, and Jan Steutel. "Taking the Right to Exit Seriously." Theory and Research in Education 4 (2006): 313-27.

117. Hacker, Daphna. "Religious Tribunals in Democratic States: Lessons from the Israeli Rabbinical Courts." Journal of Law and Religion 27 (2011-2012): 59-82.

118. Goodman, Josh. "Divine Judgment: Judicial Review of Religious Legal Systems in India and Israel." Hastings International and Comparative Law Review 32 (2009): 477-528. 
119. El Saadawi, Nawal. The Hidden Face of Eve: Women in the Arab World, 2nd ed. London: Zed Books, 2007.

120. Sadiqi, Fatima. "Women, Islam, and Political Agency in Morocco." In Women in the Middle East and North Africa: Agents of Change. Edited by Fatima Sadiqi and Moha Ennaji. New York: Routledge, 2011, pp. 36-47.

121. Raday, Frances. "The Fight against Being Silenced." In Women of the Wall: Claiming Sacred Ground at Judaism's Holy Site. Edited by Phyllis Chesler and Rivka Haut. Woodstock: Jewish Lights Publishing, 2004, pp. 115-33.

122. Chesler, Phillis, and Rivka Haut. "Introduction." In Women of the Wall: Claiming Sacred Ground at Judaism's Holy Site. Edited by Phyllis Chesler and Rivka Haut. Woodstock: Jewish Lights Publishing: 2004, pp. XIX-XL.

123. Avigail, Eisenberg. "Identity and Liberal Politics: The Problem of Minorities within Minorities." In Minorities within Minorities: Equality, Rights and Diversity. Edited by Avigail Eisenberg and Jeff Spinner-Halev. Cambridge: Cambridge University Press, 2005, pp. 249-70.

124. Tagari, Hadas. "Personal Family Law Systems-A Comparative and International Human Rights Analysis." International Journal of Law in Context 8 (2012): 231-52.

125. Halbertal, Moshe. "Who is a Jew." In Jewish Culture in the Eye of the Storm. Edited by Avi Sagi and Nahum Ilan. Tel-Aviv: Hakibutz Hameuhad, 2002, pp. 233-47. (In Hebrew)

126. Jobani, Yuval. “Three Basic Models of Secular Jewish Culture.” Israel Studies 13 (2008): 160-69.

(C) 2015 by the author; licensee MDPI, Basel, Switzerland. This article is an open access article distributed under the terms and conditions of the Creative Commons Attribution license (http://creativecommons.org/licenses/by/4.0/). 